This item was submitted to Loughborough's Institutional Repository (https://dspace.lboro.ac.uk/) by the author and is made available under the following Creative Commons Licence conditions.

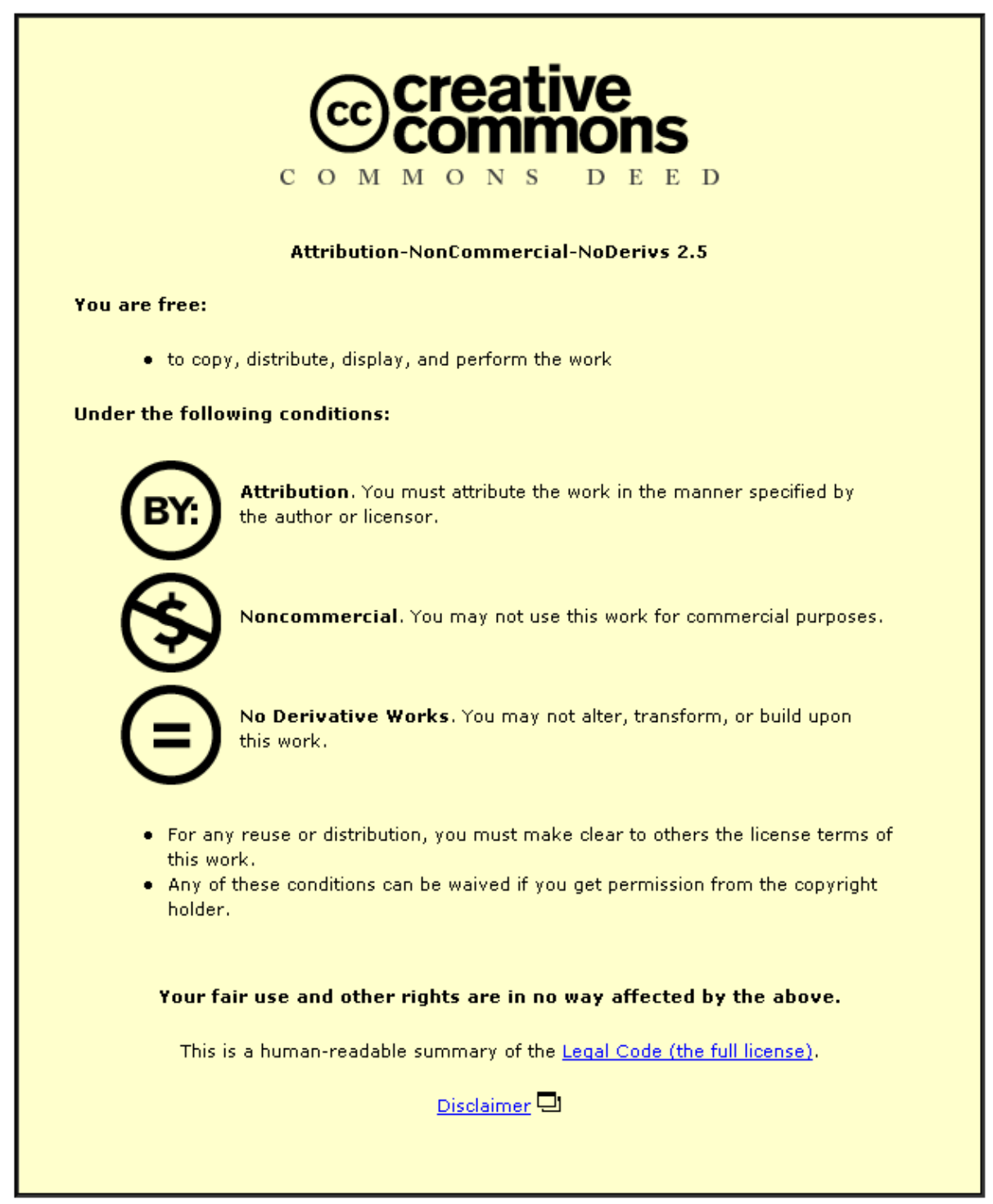

For the full text of this licence, please go to: http://creativecommons.org/licenses/by-nc-nd/2.5/ 


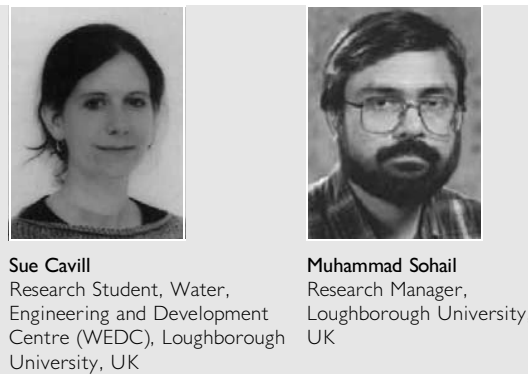

\section{Accountability in the provision of urban services}

\section{S. Cavill and M. Sohail}

This paper assesses the potential of accountability arrangements to improve the quality of local services as well as the responsiveness of services providers to the needs of users and in particular those of the poor. In the first section of this paper municipal services are embedded in a social and political context, before moving on to explore a broad set of contemporary innovations in the way services are delivered. The research on which this paper is based was undertaken in cities and so specific attention is paid to urban areas. Accountability is defined using the existing literature and the current models for accountability are presented. In the second part of the paper research from case studies in South Africa, Bangladesh and the UK are presented. These studies reveal that while the provision of urban services is often based on ethics-that is, that no one should be disadvantaged by where they live (in the UK) or that everyone should have access to services such as water, sanitation, and electricity (in South Africa)—ethics alone are not enough to ensure adequate urban services. Accountability is most effective when these ethics are translated into more tangible rights or guarantees of performance, which enable ethics to be realised. Increasingly, however, accountability is used to better manage services and their users and has been reduced to a set of technical tools and procedural measures which can be universally applied. Consequently, ethics do not necessarily function as an input to systems of accountability. In conclusion, it is recognised that accountability cannot be reduced to a technocratic, politics-free management tool but are a product of a particular socio-cultural context.

'It is not that we should simply seek new and better ways for managing society, the economy, and the world. The point is that we should fundamentally change how we behave. ${ }^{1}$

'If public bureaucracies are to serve citizens well, they must be made accountable not only for the services they render, but also for the quality and manner in which those services are delivered. ${ }^{2}$

'We shouldn't point a finger at any one individual. I have a friend in the department; we are talking about the system and not my friends. If the system is made better people will improve' (respondent from Dhaka from author's own fieldwork).

\section{INTRODUCTION}

Ethics are explored in this paper in the context of accountability for urban services. The overall aim of the paper is to assess the role of ethics and accountabilities in the provision of urban services. Other objectives are to

(a) consider contemporary innovations in the way municipal services are delivered

(b) define accountability using the existing literature and present current models for accountability

(c) discuss how ethical responsibilities can be operationalised in the context of civil engineering

(d) provide an understanding of ethics as a product of the socio-political context

(e) review the function of ethics as an input to systems of accountability

( $f$ ) present initial findings from case studies undertaken in South Africa, Bangladesh and the UK

$(g)$ examine the potential of accountability arrangements demonstrated in these case studies to improve the quality of local services and the responsiveness of services providers.

The term 'urban services' refers to water and sanitation, street cleaning, solid waste management, roads and street lighting. Some of these services are procured under sets of regulations and may involve the use of market forces. Procurement is the process of buying the goods, works or services, which in our case comprise local infrastructure in urban neighbourhoods. The main goals of urban services normally include improving quality of life, as well as the economic, environmental, governance and financial context of service provision. ${ }^{2}$ Access to urban services has social, physical and economic dimensions, reflecting competing claims over scarce resources and power relations. While low-income people are likely to benefit most from public urban services, because they are least likely to obtain acceptable alternatives, it is often the case that higherincome groups in society tend to secure better services. Sattherwaite $^{3-5}$ draws a distinction between what he calls 'income poverty' and 'housing poverty' to represent the difference between households with a below poverty line income but who have access to a free government school and health care, secure tenure, piped water and adequate provision for sanitation and drainage; and households without these entitlements who are clearly more vulnerable. The politics surrounding the provision of infrastructure frequently reinforce 
the inequities in society such as social relations of power like class, status, race, ethnicity, age and culture. ${ }^{6,7}$ Stephens ${ }^{8}$ is concerned with the process by which people are made vulnerable by other people. She makes the distinction between inequality and inequity. Inequalities in access to services may lead to health inequalities. However, if one group (usually the wealthy) benefits at the expense of another group (usually the poor), this is a health inequity. Furthermore, Ubels (cited on p. 198 of Reference 11) argues that infrastructure 'is a basis for social interaction', thus the physical state of the service must in some way reflect the quality of interaction between service providers and users. Such analysis explicitly questions the neutrality of urban service provision, based on objective criteria such as need, demand, efficiency, and resources. The discretion afforded to workers in direct contact with the public may result in less predictable outcomes. The implementation of accountability arrangements is aimed at transforming the relationship between service providers and citizens, resulting in an increase of trust and reciprocity. Increasing accountability to users for urban services is thought to enable public monitoring of service performance and quality of work, better targeting and allocation of resources and operation of services that better reflect local needs.

\section{CHANGING PROVIDERS OF URBAN SERVICES}

Public provision of urban services has been critiqued on the basis of waste of resources, lack of operation and maintenance, poor management, corruption, inefficiency, rent seeking and unaccountability, leading to inadequate services. Proponents of this view have advocated reforms of the public sector, increased private participation in service delivery, as well as the involvement of users in order to improve service delivery. The implication of this has been to fragment service delivery. Attempts to ensure quality outcomes of service delivery have resulted in an emphasis on charters, performance targets, benchmarks and consumer rights as well as the promotion of a direct relationship between service providers and users of urban services. It is generally accepted that it is much easier to achieve accountable urban services when users have face-toface contact or a personal relationship with the service provider. ${ }^{9,10}$ Where this is not possible, accountability arrangements, as a proxy for personal ethics, are instigated. Accountability arrangements can then be seen to obviate the need for ethics.

\section{ACCOUNTABILITY FOR URBAN SERVICES}

Accountability is composed of answerability (providing an account for actions undertaken) and enforceability (punishment for poor performance). ${ }^{13}$ Accountability has political, financial, administrative, legal and constitutional aspects as well as spatial dimensions. Horizontal accountability entails institutional checks and balances for holding service providers accountable to users. Citizens have also been involved directly in the workings of horizontal accountability institutions, for example participatory auditing of public spending. Goetz and Gaventa $^{12}$ call this 'diagonal accountability'. The main institutions involved in promoting vertical accountability are legal frameworks, judiciary and accounting systems, consultations with civil society, elected representatives, and media. Vertical accountability depends on awareness of rights and the willingness and ability to defend them, clarity about the procedures (for example, in procurement) and regulations for redress.
Answerability of service providers is both upward to central government and downward to services users and is to be demonstrated by carrying out agreed tasks according to agreed performance standards including financial accountability, efficiency in use of resources, effectiveness in meeting goals, consultation with stakeholders, and so on. Paul ${ }^{13,14}$ presents a model of accountability for urban services which focuses on users' micro-level decision making in terms of exit (fınding an alternative service), voice (complaining about the quality of service) and loyalty (hoping things will get better); Paul is suggesting that the general welfare of users and quality of services can best be achieved by individuals pursuing their own interests. More and more, service users are encouraged to become 'the active makers and shapers of services, exercising their preferences as consumers and their rights as citizens', ${ }^{15}$ converting what are essentially public problems into personal troubles. Castells ${ }^{16}$ thought a failing urban service is potentially a source of radical social change. However, the poor are not typically 'competent consumers', lacking the financial and political resources or technical expertise to mobilise effectively. This points to the potential for less equity in service provision, favouring those who are better at individualistic bargaining for better services. Accountability arrangements may then just be papering over the cracks of the structural causes of poor services.

\section{WHOSE ETHICS; WHOSE ACCOUNTABILITY?}

Ethics can be understood to be either a product of the sociopolitical context (such as the religion, culture or ethnic identity; family values; personal experience; peer groups or personal conscience; standards and values) or viewed as a quality innate to being human and so universally shared. Ethical responsibilities in the context of civil engineering can be operationalised in terms of not engaging or continuing action that increases injustice, the unequal treatment of persons or increasing the unfair distribution of resources. Ethical behaviour might arise from self-interest (for example the fear of punishment, the desire for rewards or for approval from superiors); alternatively ethics may be a consequence of the mandatory adherence to the standards, norms or laws of society or one's profession (such as professional codes, company codes, regulatory requirements), or ethical behaviour may arise from a utilitarian desire for fairness and social justice. In this instance, ethics as an internal moral code is subtly different from accountability, which is principally an obligation to others and where one's behaviour is regulated by others not self. An illustration of the difference between ethics and accountability in service delivery is found in the provision of urban services in illegal settlements in Bangladesh and South Africa. When interviewed, local government justified withholding municipal services from slum areas of Dhaka by labelling the poor as prostitutes, drug dealers or pimps; this is a value judgement. In South African slums, on the other hand, government provides services such as water, concerned with a rights-based and more politicised approach to service provision.

The ethics, attitudes and values that are currently said to encourage high standards of service delivery are typically associated with the private sector, for example amoral market mechanisms, efficiency, economy and effectiveness, the profit motive, material rewards and incentives to do a good job; whereas the public sector is typically associated with moral 
appeals to solidarity, mutual responsibility, public sector ethos and loyalty. Yet for Chambers (cited on p. 118 of Reference 18) individual personal change is the key to ethical service delivery, for example 'personal commitments, which seek to serve those who are weaker and more deprived'. Brown, however (cited in pp. 148-149 of Reference 18) claims this stance is to the detriment of political analysis; 'in which questions of power and authority are treated as largely subordinate to individual values and attitudes', which may risk a situation in which rights become contingent on certain values and attitudes.

The current emphasis on accountability as a means to ensure improved services embodies a new universal prescription in service provision, often adopted in developing countries through donor leverage. It might be expected that there is a linear relationship between increasing accountability and better services. However, Lipsky (cited in Reference 19) finds that the responsiveness of street-level bureaucrats to clients necessarily entails that they are less controllable by the agencies for which they work. Such controls, he argues, would reduce the quality of the service and increase the costs. Day and Klein (on pp. 231-232 of Reference 10) suggest that holding providers accountable for the performance of a service is difficult because of the variety of actors involved in service provision and the problematic relationship between inputs, outcomes and the wider social environment. Furthermore, they question whether service users are the best judge of the performance of professionals and experts.

The outcomes of accountability arrangements can be problematised in three main ways.

(a) Accountability arrangements aim to develop trust in the activities of service providers. As such 'they presuppose a culture of mistrust in professions and institutions that they themselves contribute to, produce and intensify,. ${ }^{20}$ Paradoxically, mechanisms to publicly increase transparency in service delivery may result in decreasing public visibility; 'accountability becomes reduced to meeting of pre-stated performance targets, and that activity is manipulated to show that these have been met'. ${ }^{23}$

(b) Accountability arrangements are portrayed as essentially a neutral and technical exercise but can be exercised in a discretionary and discriminatory way with different standards for different actors; "who defines accountability, for whom and why, are questions which need to be analysed very carefully' (Karim quoted in Reference 22).

(c) Accountability arrangements can be used to better manage the service providers' relationship with users. In effect, accountability arrangements narrow the scope for action when services fail, legitimising only certain strategies; complaints then become emasculated by the institutionalisation and domestification of dissent. ${ }^{23}$

\section{METHODOLOGY}

The case studies presented below are based on information collected using the case study methodology; field visits, semistructured interviews, questionnaires, secondary documents and direct observation of events including service provision. The data were collected from July 2002 to July 2003. A short case summary based on an initial data analysis from Bristol, UK and Mdantsane, South Africa and Dhaka, Bangladesh is presented.

\section{I. UK}

Project Pathfinder was launched in Barton Hill in 1999 to produce an integrated and more locally responsive solution to the delivery of waste collection, street cleaning, grounds maintenance, household bulky collections, gully emptying and recycling services at the neighbourhood level. It involves a partnership between the public sector (Bristol City Council's Neighbourhood and Housing Service), private sector (SITA GB Ltd), a non-governmental organisation (NGO), (ResourceSaver Ltd which operates the kerbside 'black box' recycling collection service in Bristol under a subcontract) and Community at Heart (a resident-led charity established to deliver the $£ 50$ million New Deal for Communities programme in Barton Hill, Redfield, Lawrence Hill and the Dings). The project also meets the new UK government policy, Targeting Social Need, aimed at tackling inequalities in service provision and promoting social inclusion, whereby resources and efforts are targeted to those in greatest need (www.newtsnni.gov.uk). Project Pathfinder is gaining national recognition for its innovative approach to neighbourhood street management and democratic, accountable service delivery. The key features of the project are detailed in the subsections below and summarised in Table 1.

5.1.1. Accountability arrangements. Accountability was changed by both opportunities to make requests or complaints in formal meetings with services providers as well as informal, face-to-face meetings with the team in the streets or in the local one-stop shop, together with the traditional channels for

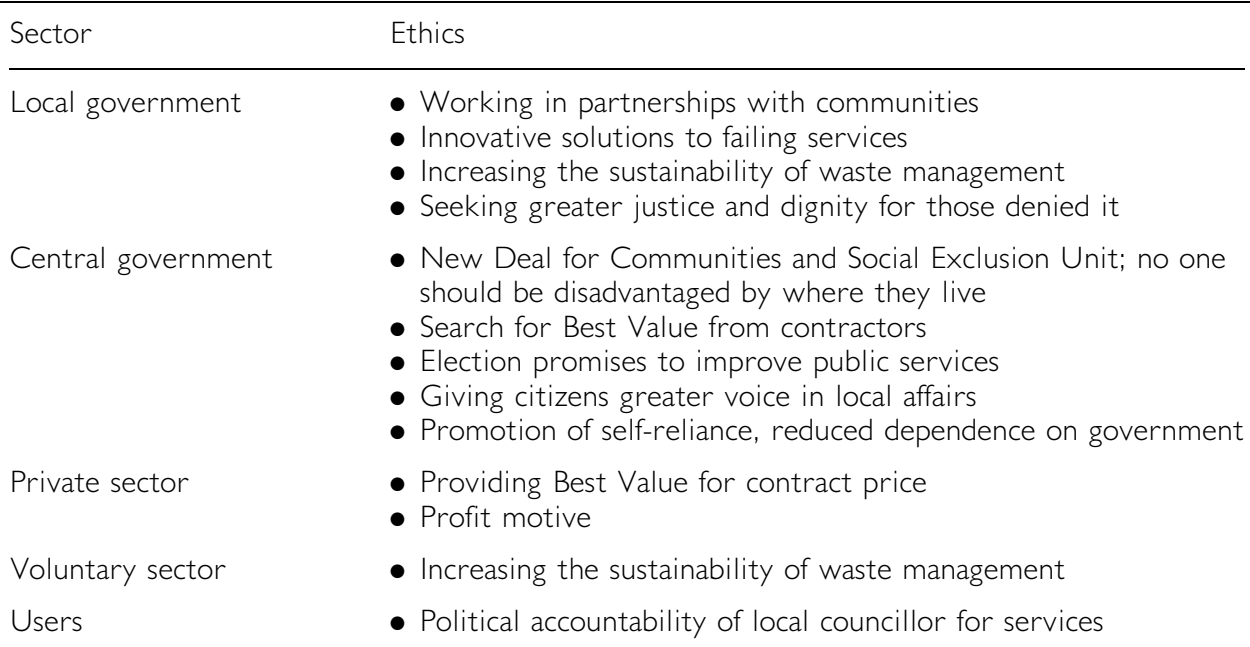

- Working in partnerships with communities

- Innovative solutions to failing services

- Increasing the sustainability of waste management

- Seeking greater justice and dignity for those denied it

Central government

- New Deal for Communities and Social Exclusion Unit; no one should be disadvantaged by where they live

- Search for Best Value from contractors

- Election promises to improve public services

- Giving citizens greater voice in local affairs

- Promotion of self-reliance, reduced dependence on government

Private sector

- Providing Best Value for contract price

- Profit motive

- Increasing the sustainability of waste management

- Political accountability of local councillor for services 
complaints/requests at Bristol City Council. The project has created a new level of accountability; residents can exert direct pressure on services providers, through useful encounters, ad hoc face-to-face personal contact, as well as the traditional monitoring from the client officer of the local authority, and intervention of the local councillor. Any pressure to adopt more formalised or professional structures of accountability may reduce this micro-level participation.

\subsubsection{User involvement in service provision. Users had the} potential for significant involvement in the planning as well as management of services, but attempts to involve residents in advisory meetings failed due to lack of interest. The project also increased residents' access to information and created space for the voices of consumers to be heard.

5.1.3. Improvements in services quality. Project Pathfinder has increased the effectiveness and efficiency of waste collection in Barton Hill as well as creating a sense of community ownership of the local environment. Staff take the time to listen, and respond in a more coherent way.

5.1.4. Improved access. Establishment of a one-stop shop for local residents means they can pop in or phone if they have a problem; the Pathfinder team can also be contacted on their mobile phones. The local one-stop shop gave residents significantly improved access to service providers, shortened lines of communication and accountability, reduced social barriers to access, and provided support for people with literacy difficulties, all of which helped raise awareness of new locally integrated services.

\subsubsection{Improved accountability in functioning. There is a} recognition of users as partners in service delivery. Efforts have been made to increase user awareness of their rights to access good-quality services in an equitable and accountable way. However, there is also a need for sufficient resources and support for improvements in services.

5.1.6. Staff conditions. The work has become more interesting, meaningful and satisfying and staff have been freer to manage their work plans. They make better use of their skills and take pride in their work and achievements; as such they have achieved higher productivity and standards of refuse collection than the other crews in the city. Demands on staff increased due to closer and more extensive contact with consumers, which meant sustained pressure to improve services, in addition to the high profile of the project for its innovative approach to waste management.

5.1.7. Unanticipated effects. The crew are described as 'the eyes and ears of our community'; they act as informal community wardens, reporting abandoned cars, crime, damaged lampposts, tackling security issues, and have become a source of local information and advice on other services such as welfare and have had a direct influence on antisocial behaviour such as vandalism and drug dealing in the area.

\subsection{South Africa}

Ethical and fair service delivery is one of the hallmarks of postapartheid South Africa, where previously services were explicitly organised around apartheid imperatives. The Constitution of the Republic of South Africa (1996) grants all citizens an equal and inalienable right to housing, health care, water and social security. South Africans have two key mechanisms for improving the responsiveness and performance of service providers: popular participation in government through direct and representative methods as well as a more results-based and client-orientated public services, under the Batho Pele (People First) programme.

Ward committees have become the preferred way of involving communities in municipal affairs. A ward committee is a specialised participatory structure, composed of ten members and designed to be a communication channel between the community and ward councillor, reporting council business and municipal performance to communities and feeding back community needs to council. Ward committees act as advisory bodies on policies affecting the wards as well as providing a mechanism for community participation in monitoring, measuring and reviewing municipal performance. The ward committee can also ensure their ward councillor accounts for his/ her actions, for the decisions taken and the promises made. The ward committees are designed to account for the special needs of previously disadvantaged groups. Ward committees are intended to be a grassroots organisation closer to residents than the local government rather than another tier of bureaucracy; however, this may result in indistinct lines of accountability between elected leadership and members of civil society working in a voluntary capacity in functions that are essentially consultative and advisory.

The following observations of accountability arrangements working in practice are based on a study of a suburb of East London called Mdantsane, which under apartheid was developed as a dormitory town in the former Ciskei, politically and administratively separate from East London and was incorporated into the city in 1997. Service provision in Mdantsane ranges from household connections for water and sewerage and tarmac roads to pit latrines and standpipes. Table 2 gives a summary.

5.2.1. Accountability arrangements. Service delivery must be transparent, open and accountable in line with Section 195 of the constitution. In addition, new rights to services have been set out by which the government can be held accountable by citizens. The Reconstruction and Development Programme standards for services delivery also give people a voice in their local government and a role in setting priorities for development planning. Batho Pele, a government campaign to improve customer service, states that there should be consultation with citizens about the level and quality of services they receive. The integrated development plan (IDP) is the principal strategic planning tool and by law under the Municipal Systems Act (2000) requires democratic accountability through community participation in strategic decisions relating to the provision of municipal services and monitoring their performance in order to improve the level, quality and effectiveness of services. The focus of the IDP is on expressed needs and community aspirations and provides a more effective way of managing resources. Central government also requires that a municipality establish a performance management system, with provision of infrastructures as key performance areas and recommends that communities should be involved in the setting of key perform- 


\begin{tabular}{|c|c|}
\hline Sector & Ethics \\
\hline Local government & $\begin{array}{l}\text { - User-orientated public services } \\
\text { - Improves access to services } \\
\text { - Managing citizens to curb their frustrations } \\
\text { - Sense of responsibility for ensuring that services reach the poor } \\
\text { - Improve democracy and community empowerment } \\
\text { - Improve community control and responsiveness } \\
\text { - Market-oriented and commercial view-cost-effective services, better value for money }\end{array}$ \\
\hline Central government & $\begin{array}{l}\text { - Social upliftment of the previously disadvantaged } \\
\text { - Political imperatives to be accountable to the majority } \\
\text { - Defined rights for certain services for the poor } \\
\text { - Seek greater justice and greater dignity for those denied it } \\
\text { - Creation of a more equitable society; equality of opportunity and access creates social justice, } \\
\text { - expression of social solidarity }\end{array}$ \\
\hline Private sector & - Consumer-orientated model of accountability - that is, through competition and payment for services \\
\hline Voluntary sector & $\begin{array}{l}\text { - Watchdog role in case local government fails to serve the poor } \\
\text { - Ensure that the poor have the resources and political space to seek accountability from governments } \\
\text { and service providers } \\
\text { - Empowering the poor to act } \\
\text { - Promote a rights-based framework to service delivery, not contingent on goodwill of individual service } \\
\text { providers }\end{array}$ \\
\hline Users & $\begin{array}{l}\text { - High expectations of ethical behaviour from service providers and government among those } \\
\text { disadvantaged by apartheid } \\
\text { - Withholding payment until services meet expectations in terms of quality and cost } \\
\text { - Community solidarity; sense that no one should be without-for example if a household's water supply } \\
\text { is cut off for non-payment, the household can access water from neighbours } \\
\text { - New rights to services } \\
\text { - Lifeline tariff for water ( } 6000 \text { litres of waterhousehold/month based on eight sharing a household) and } \\
\text { electricity supply }(50 \mathrm{kWh})\end{array}$ \\
\hline
\end{tabular}

ance indicators. The IDP process and performance management systems are intended to reform service delivery at the municipality level; to ensure sustainable, equitable, efficient, effective and affordable services. In theory, municipalities are to be held accountable for meeting IDP targets and performance indicators. Other activities specific to East London are The Mayor's Listening Campaign, The Quality of Life Survey as well as newspaper articles, media broadcasts, and public meetings.

5.2.2. User involvement in service provision. The ward committees are heavily involved in planning and setting standards for service provision in their wards. The impact is variable and not possible to evaluate fully as they have been operating for such a short time. However, a weak civil society within wards may mean councillors have not been made to account as elected representatives by their constituencies. Furthermore, user involvement is dependent on ward committee members sharing power. Provincial and central government have made provisions for more regular opinion surveys, more consumer education. The Municipal Systems Bill (1999) is focused on the rights and duties of residents and communities and makes the link between rights and duties, Masakhane and payments for services, residents' responsibility in matters of local municipality with special reference to attendance of council meetings, and involvement and participation in decision making.

5.2.3. Improvements in service quality. The Municipal Systems Act (2000) set out the need for a system for monitoring efforts to address service delivery backlogs, quantify development needs and prioritise development initiatives through IDP. Monitoring is achieved by establishing a performance management system based on indicators. This scheme is in line with national requirements that require local government to move towards indicators based systems of performance assessment. The increased voice of consumers is expected to lead to further improvements in due course. However, more significant improvements depend on larger budget allocations to operation and maintenance of services, improved training and management, capacity, IT and service performance targets.

5.2.4. New rights. All South Africans must have access to water, sanitation, electricity, rubbish removal and other services by way of a lifeline amount of basic services based on the principle of cross-subsidisation. While physical access has greatly increased, coverage is not universal. There have been various campaigns to increase service efficiency at a national and provincial level.

5.2.5. Improved access. Municipalities are expected to be developmental as stated in the Local Government White Paper, and is responsible for the implementation of the lifeline tariff. Local government has the option of making use of the private sector to increase access by the poor to essential services, provided they can effectively deliver services at substantially higher levels of quality, cost and coverage than alternative providers. This means decentralised service provider offices along with improved mechanisms for personal, written and 
telephone contact in case of complaint; increased access to local government and service providers through local ward committee members.

5.2.6. Improved accountability in functioning. South Africa is characterised by organised civil society. The new democracy emphasises accountability and responsiveness to the excluded. Users tend to be aware of their rights to be involved in service delivery and to access good-quality services. There is debate in civil society about the policy of the cost recovery basis for service delivery and enforcing cut-offs for non-payment of bills. There is a changing relationship between providers and users: central government is now trying to change the strategy of non-payment for services used during apartheid; now there are attempts to channel user complaints through the mechanisms of local democracy such as ward committees with attention to involving minorities who have less influence in decision making.

\subsubsection{Information dissemination. Ward committees are an} instrument for monitoring the performance of their local authorities while at the same time holding their councillors accountable; they are also used to encourage community participation in the shaping and development of IDP, thus information about services has improved. Local municipal offices can handle all aspects of work, and telephone reporting has greatly enhanced access for service users; ward committees and the ward councillor act as advocates, representing gains in social accessibility.

5.2.8. Staff working conditions. The content of work and the performance standards expected became more exacting, so that jobs became more arduous. There was limited recognition of this by local government or of the difficulty of working closer to the consumers without adequate training and equipment, management or remuneration to balance increased responsibilities and pressure.

5.2.9. Unintended impacts. The influence of users over service managers has grown, but there is a danger that they will be coopted by the ward committee system rather than challenging local government. Ward committee members, however, report feeling threatened by residents, sometimes because of their political affiliations but also reflecting the frustration with the slow pace of change and delivery of services. Consultation with users has made life more difficult for staff as they have struggled to adapt to more knowledgeable and powerful users. These initiatives have occurred in a context of limited resources-that is, finances, skills, technical and personnel to assist local authorities. Local authorities have been unable to provide the requisite information to ensure realistic budgeting and often lack the capacity to plan effectively.

\subsection{Bangladesh}

Getting connections to services (water, sewerage, electricity) takes time. It is usually quicker to circumvent the system through unofficial payments; these may be asked for by officials or paid by users in anticipation of problems with officials. Even when a connection is received, the supply remains unpredictable, users complain of regular power outages, low water pressure, and infrequent garbage collection. Resolving problems usually necessitates further under-the-table payments. Dhaka City Corporation has a grievance redressal system for complaints about its services; however, only a small proportion of households are aware of it or bother to use formal mechanisms because citizens generally feel that there will be no follow-up to their complaint. Officials are often not available or indifferent and uncooperative in providing assistance; alternatively citizens get passed from one official to another because staff lack proper information on services, or are unaware of rules and procedures. Dealings between service providers and users are not always direct; sometimes users may be required to go through influential intermediaries (middlemen, political leaders, influential persons, friends and neighbours) to accelerate access. These intermediaries may be mastaans (muscle men) who facilitate 'illegal' connections to essential services such as electricity and water and in turn pay bribes to officials to stay in business. ${ }^{24}$

Attempts to improve the efficiency and responsiveness of urban service delivery in Dhaka have included calls for reforming the role of state and instituting a system of accountability that makes service providers answerable to service consumers. None of the utilities guarantees a minimum quality or level of service or measure user satisfaction. A further feature of service delivery in Dhaka is increasing partnerships with profit and non-profit service providers. However, the involvement of the private sector may 'mirror and reproduce social patterns of discrimination and exclusion, affecting the capacity of different poverty groups to gain access to resources and to realise entitlements'. ${ }^{25}$ Table 3 gives a summary.

\subsubsection{Accountability arrangements. There is a general resigna-} tion to corruption in service delivery by service users and providers. It is regarded as a kind of necessary evil; corrupt practices ranged in scale from bribes between customers and ground-level workers or using influential contacts to pressure front-line workers to do repair work quickly, expedite the approval of new connections, for meter readers to record a reduced level of water consumption, and at the other end of the scale corruption in construction contracts and procurement. There are some consumer opinion surveys, usually conducted by NGOs, but otherwise consumers have little formal influence on utilities; public reactions expressed through the newspapers may cause temporary modifications to service delivery. Lodging complaints is a trade-off between paying cash for speedy resolution or paying with time and effort needed to resolve a problem. However, service providers are accountable to those who can pay bribes as well as powerful or influential service users; this scenario can work to the benefit of the poor if they can secure access to a patron or local politician. Political accountability typically rests on the premise that the citizens of Dhaka elected them, after which citizens have no easy mechanism to make them take their interests into account. Accountability for urban services is typically confused; Dhaka City Corporation is taken to task by the press and public for inadequate services, even when these do not fall within its functional jurisdiction.

5.3.2. User involvement in service provision. In the day-to-day operations of Dhaka City Corporation/Dhaka Water And Sewerage Authority consumers have little influence; information and participation are not an objective of service delivery. Service providers lack the resources to enable user involvement 


\begin{tabular}{|c|c|}
\hline Sector & Ethics \\
\hline Local government & $\begin{array}{l}\text { - Instances of officials with a social conscience } \\
\text { - Inability to meet responsibilities through lack of resources } \\
\text { - Responsiveness to powerful (money or influence) } \\
\text { - Discrimination against certain citizens }\end{array}$ \\
\hline Central government & $\begin{array}{l}\text { - Rated as the most corrupt country by Transparency International } \\
\text { index }\end{array}$ \\
\hline Private sector & - Profit motive \\
\hline Voluntary sector & $\begin{array}{l}\text { - Solidarity with slum dwellers } \\
\text { - Raising consciousness of slum dwellers } \\
\text { - Creation of more equitable society, equality of opportunity and access } \\
\text { to services-social justice }\end{array}$ \\
\hline Users & $\begin{array}{l}\text { - Civil resistance to meet collective needs } \\
\text { - Service delivery as disempowering, no information, access, frustration, } \\
\text { - Accost, defeat } \\
\text { - Extra paymentability for services from local politicians } \\
\text { - } \text { fotter services }\end{array}$ \\
\hline
\end{tabular}

dwellers, major gains have been made in access through NGO intermediaries. For example, one NG0, Dusthya Shathya Kendra (DSK), has been working in slums to smooth the process for utility approval of legal, safe water connections. However, such examples are patchy and have not resulted in a formal recognition of rights to water. In all aspects of service delivery there is a dominance of élite (socalled VIP) interests. Service provision and repair activities are influenced by politicians, who may make complaints or special requests on behalf of residents, which may

and service users reported a lack of the technical and financial knowledge for effective monitoring of service delivery, not only among residents with low levels of education but also among more educated residents. Politicians and local élites influence service delivery in their areas as a vote-winning strategy. User involvement in service delivery is typically linked to NGOs; Dhaka City Corporation abdicated some responsibilities for service provision because it could not afford to provide quality, coverage, and sustainable services. Waste Concern, a Dhakabased NGO, initiated a small-scale, community-based organic waste recycling project. Household waste is collected door-todoor in predominately middle-class areas that are dissatisfied with Dhaka City Corporation's service. The majority of NGOs, however, that are involved in service delivery in Dhaka are serving the urban poor. The strategy of the poor has been one of exit from municipal supply whereby NGOs have been undertaking public service functions. However, the feedback mechanism is missing, as exit has not increased the political cost of inadequate services or induced increased competence in municipal service delivery. In fact, exit from municipal supply by the poor has in effect endorsed the privilege of certain people in service delivery. This is in part because the poor lack the organisational strength for a sustained dialogue with Dhaka City Corporation; for example, voice is typically demonstrated by protest marches.

5.3.3. Improvements in service quality. Service quality can be characterised as slow, unreliable, unresponsive, inflexible with essentially bureaucratic and centralised rules and procedures and pervasive corruption. The relationship between Dhaka City Corporation and NGOs has led to dramatic improvements for slum dwellers, including a reduction in the power differentials that normally characterise the relationship between slum dwellers and service providers; for example, access to a legal water connection has led to a demand pull on the City Corporation for other services as well as demands for more significant social change.

5.3.4. New rights. While it is not the legal responsibility of Dhaka City Corporation to supply services to slum/squat benefit the slum dwellers at election time.

5.3.5. Improved access. Service providers are inaccessible, users are disempowered, bureaucracy is mystified and staff have little knowledge of the problems faced by users or little empathy with them. There is limited access to systems of help in accessing services or complaint systems to deal with problems; service providers are not geared towards those most in need. Offices are confusing: there is no reception/help desk for providing assistance to users, and similarly no signs or noticeboards. There is a significant vulnerability of users in interaction with agencies.

\subsubsection{Improved accountability in functioning. Service providers} are typically seen as remote, impersonal and inefficient. Accountability of service providers is typically bought through pervasive corruption ${ }^{26}$ : civic and political rights are not acknowledged and entitlements are not met. The poor and slum dwellers typically have weak capabilities to demand better services and instead rely on patron-client relations or organised civil society. Political processes are weak, as are constitutional checks and balances as well as the rule of law. The Press helps disseminate information and, together with anti-corruption groups, exerts pressure to improve services. Centralisation of service delivery has created long delays and a lack of accountability and a user perspective in service delivery. Issues of citizenship and rights are unimportant and user alliances with key actors are important for those who are unable to represent themselves.

\subsubsection{Information dissemination. Local zonal offices together} with ward commissioners are intended to bring service delivery to the local level and reduce social barriers to access; however, limited information is available to users about services. Committees of Concerned Citizens (CCCs), set up by the local Transparency International chapter, are self-help groups of individuals working to combat corruption in their localities; they collect and disseminate information on local priorities. CCCs are also involved in corruption surveys, rating municipal services and lobbying for change. 
5.3.8. Staff working conditions. Service delivery in Dhaka is limited by: employee discretion and intimidation; centralised rules and control as well as lack of other resources; lack of staff skills and IT; inadequate equipment; lack of supportive procedures; poor supervision, management and remuneration; lack of motivation and commitment; responsibilities not matched by financial rewards for front-line staff. There is anecdotal evidence of a market for desirable jobs; for example, meter reading is popular because of the high bribe-generating potential.

\subsubsection{Unintended impacts. The frustration of some residents} has occasionally led to threats to service providers, for example kidnaps or violent protests. NGO involvement created increased demand for new services or for different sorts of services and for more of existing services, giving power and influence to consumers.

\section{GENERAL FINDINGS}

The general findings of this study can be summarised as follows.

(a) Internationally, there has been a change of ethics in municipal service provision from serving the public interest to promotion of privatisation, liberalisation, and competition. However, government still has a role in ensuring accountable delivery of urban services. The case studies reveal the role of central government in driving initiatives in expanding accountability and ensuring access and the adequate performance of services.

(b) Local service providers are being made more answerable to locally elected people's representatives as well as to the users themselves within a limited geographical area. Face-to-face interaction with users on a daily basis changes the attitude of those on the front line, developing workers' pride and motivation in maintaining adequate services.

(c) Involving services users is a new mechanism for increased monitoring of technical staff. User involvement in decision making and community vigilance in monitoring services is said to result in more efficient, accountable and transparent service delivery. However, residents do not always have the capacity for monitoring; community involvement may in fact be transferring responsibility.

(d) People with more power, skills, information and resources seem better able to use the tools aimed at creating social justice for their own ends, further buttressing their privileged position.

(e) Accountability can be achieved through oversight bodies (audit of public accounts, ombudsmen, anti-corruption agency, parliamentary committees and legal reform); agency reforms (personnel management, detection and measurement, oversight; job requirements, salaries, objectives, incentives, performance audit, and training); enhancing transparency and information levels (open budgets, freedom of information, service notice-boards, transparency, disclosure by officials; surveys, report cards, diagnostic studies, direct monitoring by citizen advocacy groups).

(f) Instituting accountability mechanisms is becoming a technocratic activity, a means of ensuring agreed tasks are carried out according to agreed performance standards.
This reduces the opportunity for citizens to seek accountability by articulating demands in mainstream political discourse, as well as reducing the level of discretion afforded to ground-level workers, meaning that personal ethics are less relevant to achieving accountability.

(g) Public pressure helps make government accountable and enhances service performance. Government has a central role in fostering transparency and accountability in the delivery of services. In interviews, when asked whom users of services hold ultimately accountable, the clear majority replied the government, even when the services in question were outside their jurisdiction. This highlights the importance of the quality of local democracy in safeguarding entitlements to services.

(h) Making urban services more accountable is not a process of realising an abstract principle or applying a universal prescription, so much as one of locally constructing what accountability means in a particular context.

(i) Sometimes accountability is a one-shot affair, critically dependent on the role of a few individuals. Accountability is not achieved once and for all but takes place on a piecemeal basis, evolving from the needs and experience of context.

\section{CONCLUSIONS}

The overall aim of this paper has been to assess the role of ethics and accountability in the provision of urban services. A brief review of existing literature was used to consider contemporary innovations in the way municipal services are delivered as well as to define accountability. Following this, research from the UK, South Africa and Bangladesh was presented. The potential of accountability arrangements to improve the quality and responsiveness of local services has been discussed with reference to general findings from these case studies.

The provision of urban services can be viewed as the fulfilment of an ethical ideal: for example, no one should be disadvantaged by where they live in the UK; or that everyone should have access to water, sanitation, and electricity in South Africa. Other ethics operationalised in the context of effective service delivery in the case studies include social solidarity, responsibility, responsiveness, non-arbitrary decision making, transparent resource allocation, trust, quality, democratic participation, social equity and environmental protection. These ethics stand in contrast with current municipal service delivery in Dhaka. The case studies demonstrate how, in order to be made effective, ethics are often translated into more tangible rights or guarantees of performance. The mechanisms illustrated in the case studies for improving accountability include: meeting central and local government targets and policy directives; indicator-based systems of performance assessment; reliance on quantitative measurements (such as user surveys, report cards, audits, objectives and so on); the creation of open democratic structures; promotion of dialogue between providers and users; and shortening lines of communication.

Initial findings from case studies undertaken in South Africa, Bangladesh and the UK have been used to assess the function of ethics as an input to systems of accountability. Paradoxically, while these arrangements make it feasible for service users to enforce standards and check service providers' action, it also 
means that accountability as an ethic is reduced to a quantifiable, 'best practice' management tool for universal application. Internationally, there is a pressure on local service providers to demonstrate accountability and a new generalised approach for solving accountability problems has developed, which emphasises a set of generic tools and approaches rather than a critical reflection on an understanding of the determinants of lack of accountability in that context. As currently practised, therefore, accountability is not automatically an issue of personal ethics. ${ }^{*}$ The case studies illustrate the danger of divorcing accountability from its historical, political, cultural and economic context. For people to effectively articulate the demand for an accountable government and performanceoriented services, they require a socio-political environment that facilitates the capacity to act and ability to get a response- - that is, access to information, effective oversight systems, credible sanctions, clear responsibilities, independent media, political consciousness, social awareness of rights, political history, the role of parliament, independent judiciary, neutral civil servants, rule of law, decentralisation, political will, civic pressure groups and so forth.

Furthermore, the case studies reveal that overly formalising the mechanisms can be detrimental where other mechanisms may be more important in shaping service delivery. Service users, for example in low-income communities, may prefer to resolve their problems through the ad hoc use of face-to-face contact in the streets outside public meetings, formal organisations and offices. This finding suggests that there is potential to renew the role of shared ethics in service delivery: on the supply side the desire and ability to be responsive to all service users and to provide efficient and effective services; but also on the demand side for users to overcome apathy and indifference to service provision and exert direct pressure on service providers, while also reconnecting service delivery to local democracy.

\section{ACKNOWLEDGEMENTS}

The authors would like to acknowledge the assistance of Community at Heart, Project Pathfınder team; Afesis Corplan and Transparency International Bangladesh, service provider agencies as well as communities for their assistance in the preparation of this paper.

\section{REFERENCES}

1. Chambers R. Institute of Development Studies Discussion Paper 347, Brighton. 1995, p. 1.

2. SCHUBELER P. Participation and partnership in urban infrastructure management. In Urban Management Programme Policy Paper 19. World Bank, Washington DC, 1996.

3. RODGERS G. What is special about a social exclusion approach? In Social Exclusion; Rhetoric, Reality, Responses (Rodgers G., Gore C. and FigueIredo J. (eds)), Contributions

\footnotetext{
* Whether the provision of urban services has developed as an ethical ideal is contested. Historical analysis of the development of municipal services in the UK is ambivalent, public action to create municipal services can be seen as an altruistic decision to satisfy public need, while others may view it as an attempt to preserve the status quo (public order, labour relations, political support). ${ }^{27}$
}

to the World Summit for Social Development, Geneva, IILS, 1995.

4. SATtheRWAIte D. Urban poverty; reconsidering its scale and nature. IDS, Vol. 28, No. 2, 1997.

5. SATTHERWAITE D. The underestimation of urban poverty and of its health consequences. Third World Planning Review, 1995, 17, No. 4, iii-ix.

6. Narayan D., Chambers R., Shah M. K. and Petesch P. Voices of the Poor; Crying out for Change. Oxford University Press, 2000.

7. Castells M. The Urban Question: A Marxist Approach. Edward Arnold, London, 1977.

8. STEPHENS C. Healthy cities or unhealthy islands? The health and social implications of urban inequality. Environment and Urbanisation, 1996.

9. DAY P. and KleIN K. Accountabilities, Five Public Services. Tavistock, London, 1997.

10. YIN R. Changing Urban Bureaucracies. Lexington Books, Farnborough, Hampshire, 1979.

11. GoETZ A. M. and Jenkins R. Hybrid forms of accountability; citizen engagement in institutions of public sector oversight in India. Public Management Review, 2001, 3, No. 3, 363-383.

12. Goetz A. M. and Gaventa J. Bringing Citizen Voice and Client Focus into Service Delivery, Institute of Development Studies Working Paper 138, Brighton, July 2001.

13. Paul S. Accountability in Public Service: Exit, Voice and Capture. World Bank, Policy Research and External Affairs Working Papers, WPS 614, 1991.

14. PaUl S. Accountability in public services: exit, voice and control. World Development, 1992, 20, No. 7, 10471060.

15. Cornwall A. and Gaventa J. From Users and Choosers to Makers and Shapers; Repositioning Participation in Social Policy. IDS Working Paper 127, Brighton, June 2001.

16. Castells M. The City and the Grassroots; A Cross-cultural Theory of Urban Social Movements. Edward Arnold, London, 1983.

17. YIN R. Conserving America's Neighbourhoods. Plenum Press, New York, 1982.

18. Minogue, Polidano and Hulme (eds). Beyond the New Public Management: Changing Ideas and Practices in Governance. Edward Elgar, Cheltenham, 1998.

19. Greer S., Hedlund R. D. and Gibson J. L. Accountability in Urban Society: Public Agencies Under Fire. Sage Publications, USA, 1979.

20. DeAN M. Governmentality; Power and Rule in Modern Society. Sage Publications, London, 1999.

21. Walsh K. Public Services and Market Mechanisms; Competition, Contracting and the New Public Management. Macmillan, Basingstoke, 1995, p. 215.

22. EdWARdS M. and Hulme D. Non-Governmental Organisations-Performance and Accountability: Beyond the Magic Bullet. Earthscan, London, 1995, p. 117.

23. Hirschman A. 0. Exit, Voice and Loyalty: Responses to Decline in Firms, Organisations and States. Harvard University Press, Cambridge, MA, 1970, p. 124.

24. World BANK. Proshika, Survey and Research System, Bangladesh; Urban Service Delivery; A Score Card. World Bank, Washington DC, May 2002. 
25. GoETZ A. M. and O'BriEN D. Governing for the common wealth? The World Bank's approach to poverty and governance. IDS Bulletin, 1995, 26, No. 2, April, Brighton, IDS.
26. LEWIS D. Corruption in Bangladesh; Discourse, Judgements, Moralities. Centre for Development Studies, 1996, Occasional Paper 05/96.

Please email, fax or post your discussion contributions to the secretary by I June 2004: email: kathleen.hollow@ice.org.uk; fax: +44 (0)20 7799 1325; or post to Kathleen Hollow, Journals Department, Institution of Civil Engineers, I-7 Great George Street, London SWIP 3AA. 